\title{
STRATEGI SEKOLAH DALAM PENGUATAN PENDIDIKAN KARAKTER BAGI SISWA DENGAN MEMAKSIMALKAN PERAN ORANG TUA
}

\author{
Yessy Fusvita Dewi \\ yessyfusvita@gmail.com
}

\begin{abstract}
ABSTRAK
Orang tua merupakan peranan penting dalam membentuk dan mengembangkan karakter anakanak. Oleh sebab itu, sekolah menciptakan kolaborasi dengan orang tua secara harmonis dalam membina karakter siswa. Penelitian ini bertujuan untuk bagaimana sekolah menerapkan strategi untuk memperkuat karakter anak dalam memaksimalkan peran orang tua. Jenis penelitian ini adalah penelitian deskriptif kualitatif, data dikumpulkan melalui wawancara,observasi dan dokumentasi. Hasil penelitian ini menunjukkan bahwa peran orang tua dalam memperkuat karakter siswa dan hasil implementasi program pembangunan karakter siswa.
\end{abstract}

Kata kunci : Strategi untuk memperkuat karakter siwa,peran orang tua, karakter siswa.

\section{LATAR BELAKANG}

Dalam UU No 20 Tahun 2003 membahas tentang pendidikan nasional, semua jenjang pendidikan memiliki peranan penting untuk mewujudkan tujuan pendidikan nasional tersebut, dengan fungsi untuk mengembangkan serta membentuk watak peradapan bangsa yang bermartabat untuk mewujudkan cita-cita bangsa.

Pendidikan yang mengarah dalam pembentukan karakter dan budi pekerti generasi muda bangsa,pendidikan karakter merupakan penciptaan lingkungan sekolah yang membantu siswa dalam perkembangan etika,tanggung jawab melalui model dan pengajaran karakter yang baik. 


\section{KAJIAN LITERATUR}

Ahmad dkk (2017) menyatakan bahwa pendidikan berkarakter sangat penting ditingkatkan. Melihat masyarakat Indonesia sendiri lemah sekali dalam penguasaan soft skill. Menurut Suprapto (2014) pendidikan karakter tidak sekedar mengajarkan mana yang baik atau yang salah saja melainkan menanamkan kebiasaan tentang hal mana yang baik,dengan begitu akan memiliki efek terhadap kognitif,afektif,moral/action dan psikomotor anak.

Kristiawan (2016) Ada 3 fungsi utama pendidikan karakter diantaranya : pertama, fungsi pembentukan dan pengembangan potensi siswa dan berperilaku sesuai falsafah pancasila, kedua, fungsi perbaikan dan penguatan dalam peran keluarga,pemerintah,satuan pendidikan, masyarakat dalam pengembangan potensi warga Negara, ketiga, fungsi penyaring dalam memilah budaya bangsa sendiri dan bangsa lain yang tidak sesuai dengan nilai-nilai dan karakter yang bermartabat.

Di Indonesia nilai-nilai pendidikan berkarakter bersumber dari,pancasila,agama, budaya dan tujuan pendidikan nasioanal. Pendidikan karakter adalah suatu kegiatan yang mendidik dan diperuntukkan bagi generasi masa depan. Tujuannya yaitu untuk membentuk perbaikan diri/kemampuan diri kearah yang lebih baik. Maka sebab itu pendidikan karakter seharusnya bisa membawa dampak yang baik. Pendidikan karakter dengan proses kontinyu(berkelanjutan) dan konsisten.

Pendidikan karakter ini sangat penting oleh karena itu dilakukan dalam waktu yang sangat panjang serta tidak bisa dilakukan dalam satu kegiatan saja. Jika terjadi isu dunia, rusaknya nilai,moral dan perilaku generasi muda saat ini, hal itu membutuhkan tindakan yang kuat yang menjadi factor utama pembentukan karakter yaitu lingkungan tempat tinggal yakni lingkungan keluarga. Perkembangan anak dipengaruhi oleh cara orang tua mendidik,ekonomi, suasana rumah serta interaksi antar anggota keluarga. Pembentukan potensi anak akan terbentuk dari pengalaman dan aktifitas positif dari keluarga dan sebaliknya. Jadi peran orang tua sangat penting dalam pembentukan kepribadian dan kopetensi anak di lingkungan keluarga. Nah pihak sekolah membina hubungan yang baik dengan orang tua dimana sama-sama untuk membina anak didik untuk itu dengan diadakannya strategi yaitu cara/upaya dalam memaksimalkan peran orang tua bagi siswa.

Metode penelitian yang dilakukan adalah penelitian deskriptif kualitatif untuk mengungkap strategi sekolah dalam memaksimalkan peran orang tua sebagai upaya dalam pembentukan karakter anak. Subjeknya ialah kepala sekolah, siswa, guru. Teknik yang digunakan adalah wawancara,observasi, dan dokumentasi. 


\section{PEMBAHASAN/KAJIAN ANALITIS}

Menurut Yeni Wulandari (Wulandari, 2017) Strategi sekolah dalam upaya memaksimalkan peran orang tua dalam penguatan karakter diantaranya : Mewujudkan kegiatan real sehari-hari dengan mengangkat nilai karakter sebagai visi,misi dan tujuan, menciptakan hubungan yang harmonis dan kuat dalam proses penguatan nilai karakter bagi siswa, memilih pendidik yang memiliki jiwa pendidik yang tinggi sehingga lebih mengutamakan tugasnya dan bertanggung jawab terhadap pembentukan karakter anak, menciptakan lingkungan yang islami, bersih, dan nyaman. Sebagaimana dikemukakan oleh Sabandi (Sabandi, 2013) Pendekatan budaya organisasi pembelajaran dilakukan dengan menciptakan lingkungan baik fisik maupun nonfisik yang memungkinkan tumbuhnya budaya belajar dalam organisasi.

Hal-hal yang menunjang efektifitas penerapan strategi ini diantaranya : kondisi dari lingkungan sekolah tersebut seperti dengan masyarakat sekitar sekolah, pihak sekolah dan stake holder ikut serta atau berpastisipasi dalam mensukseskan pendidikan karakter, program sekolah terlaksana sesuai dengan adanya sumber daya, keuangan dan fasilitas sekolah.

Hasil pencapaian pelaksanaan program pembentukan karakter ini diantaranya : Mengucapkan salam antar sesame, baik itu dengan kepala sekolah,guru mauun sesame teman serta dengan karyawan, memiliki toleransi dan saling menghormati missal dengan memilih teman bergaul,teman belajar, perbedaan agama dan latar belakang social, kejujuran terhadap apapun, kesopanan terbiasanya mengucapkan terima kasih dan meminta maaf, ciri akhlak mulia dengan terbiasa memulai pelajaran dengan membaca Al-Quran, kepedulian terhadap lingkungan, membersihkan ruang kelas, membuang sampah.

Maunah (2015) hasil penelitian, pengeleloaan pendidikan karakter terbagi 2 yaitu internal dan ekternal, strategi internal dengan 4 pilar dan strategi eksternal melalui kerja sama orang tua dan masyarakat dan orang tua.

\section{KESIMPULAN}

Sekolah dalam upaya memaksimalkan peran orang tua dalam penguatan karakter diantaranya : Mewujudkan kegiatan real sehari-hari dengan mengangkat nilai karakter sebagai visi,misi dan tujuan, menciptakan hubungan yang harmonis dan kuat dalam proses penguatan nilai karakter bagi siswa, memilih pendidik yang memiliki jiwa pendidik yang tinggi sehingga lebih mengutamakan tugasnya dan bertanggung jawab terhadap pembentukan karakter anak, menciptakan lingkungan yang islami, bersih, dan nyaman.

\section{SARAN}

Sekolah harus dapat memaksimalkan peran orang tua dalam upaya penguatan karakter siswa, serta pendidikan karakter yang berkelanjutan akan terkendala apabila tidak ada koordinasi yang kuat antara sekolah dan orang tua, selain itu peran orang tua dalam memberikan kebutuhan bagi anak. 


\section{REFERENSI}

Sabandi, A. (2013). Supervisi Pendidikan Untuk Pengembangan Profesionalitas Guru Berkelanjutan. Pedagogi, Jurnal Ilmiah Ilmu Pendidikan, XIII(2), 1-9. Retrieved from http://ejournal.unp.ac.id/index.php/pedagogi/article/view/4275

Wulandari, Y. (2017). Strategi Sekolah Dalam Penguatan Pendidikan Karakter Bagi Siswa Dengan Memaksimalkan Peran Orang Tua. Manajemen,Kepemimpinan Dan Supervisi Pendidikan, 2(2), 290-303. Retrieved from https://jurnal.univpgripalembang.ac.id/index.php/JMKSP/article/view/1477 